proceeds would be taxable under the alternative test-payment of premiums ${ }^{31}$-which undoubtedly applies. ${ }^{32}$

The purpose of Section $811(\mathrm{~g})$ is to tax wealth passed at death in the form of insurance proceeds. Accurate application of the Le Gierse test would achieve this result. Under the Tax Court's construction in Estate of Strauss, however, the substantial sums transferred through this and similar death benefit plans-functionally, if not nominally, insurance-are permitted to escape their just tax burden. ${ }^{33}$

\title{
THE NEED FOR CORAM NOBIS IN THE FEDERAL COURTS
}

WHILE the principle of finality of judgments may be important enough to override individual property interests, it is a pale excuse for leaving intact an unjust criminal verdict. The incarcerated victim of an unjust conviction clearly deserves his freedom. But the victim who has served his time is also entitled to relief-completion of sentence does not erase the adverse effects of a felony conviction. Former convicts may be ineligible for naturalization, ${ }^{1}$ military service, ${ }^{2}$ and certain civil rights such as voting or holding

31. Cf. Kernochan v. United States, 29 F. Supp. 860 (Ct. Cl. 1939) (payments to the N.Y. City Employees' Retirement Fund) ; Estate of Wilson, 42 B.T.A. 1196 (1940) (N.Y. City Teachers' Retirement Fund). But cf. 1 Paur, Federal Estate and Gift Taxation $\S 10.10$ (1942).

32. If a member did not possess incidents of ownership after January 10,1941, the proceeds are includible in the gross estate only to the extent of the ratio which the premiums paid after that date bear to the total premiums paid. Revenue Act of 1942, $\$ 404$ (c), 56 Stat. 944 (1942). If, therefore, the members of the Gratuity Plan were held to have possessed no incidents of ownership, a finding that they have paid "premiums or other consideration" after January 10, 1941 is required for taxability of any portion of tho proceeds.

Superficially, this would seem to call for complete exclusion of the Strauss procceds, assuming a finding that no incidents of ownership were present, since Strauss paid no cash assessments after 1941. Actually, however, the credits which he received were made partially possible by his previous excessive donations. See note 4 supra. Such advance payment of premiums should have satisfied the statutory requirement.

Assuming a contrary finding, however, taxability of future Gratuity Plan payments is not impaired, since assessments have been paid to the fund in recent years. Sea note 4 supra. This, of course, is sufficient to satisfy a "direct payment" interpretation of the premiums test.

33. The Strattss holding also has a bearing on the thirty-seven state estate tax statutes, since, when applicable, they take federal standards as their basis for measuring the gross estate. CCH TAX Systems 238-9 (11th ed. 1948). See N.Y. TAX Law, Art. 10-C, §249-r 9.

1. In re Spenser, 22 Fed. Cas. 921 , No. 13,234 (C.C.D. Ore. 1878). Aliens guilty of crimes are also ineligible for admission to the United States and if admitted are subject to 
office. ${ }^{3}$ They may be expelled from or denied access to such professions as law and medicine." And they are in danger of stiff sentences for any subsequent conviction in states having recidivist statutes. Both state and federal courts allow an accused additional opportunities to attack a conviction even after he has lost on direct appeal. Some state courts, however, extend opportunities to ex-prisoners which federal courts do not.

In addition to habeas corpus, which is available only to prisoners, relief in some state courts may be obtained through the common law writ of error coram nobis. ${ }^{6}$ This writ may be brought in the sentencing trial court any

deportation even though they have been pardoned. 3 Dep's of Justice, Survey of RELEASe Procedures [hereafter cited as Survey] 289 (1939).

2. Originally ex-felons were absolutely barred from military service 19 SrAr. 242 (1877). Subsequently an exception was made with respect to pardoned convicts. But in 1938, this exception was withdrawn. 39 OPS. ATr'Y GEN. 132 (1938). Shortly after the outbreak of World War II, conferences between correction workers and the War Department resulted in amendment of the statute to allow the Secretary of War to exercise his discretion in the admission of ex-felons. 55 STAT. 606 (1941), 10 U.S.C. $\$ 622$ (1946). Under this amendment, paroled and pardoned convicts entered the armed forces during World War II and served honorably, refuting contentions that they were untrustworthy. See generally Deessler, Parolezs in the Arxied Forces (1948).

3. In addition ex-felons may be incompetent as witnesses or jurors. At present, pardon is the only way in which these rights can be restored. 3 Survey 270 et seq. See appeal made on behalf of conscientious war objectors, N.Y. Times, Dec. 19, 1949, p. 5, col. 4.

To restore lost civil rights, some states grant pardons several years after release, while in Pennsylvania completion of sentence has the effect of a pardon. PA. Srar. Aswr. tit. 19, $\$ 893$ (Purdon, 1930). To facilitate restoration of lost civil rights Connecticut recently created a "Forfeited Rights Commission" to replace the cumbersome pardon procedure See N.Y. Times, Jan. 12, 1950, p. 7, col. 3. For a discussion of similar reform in New York see 19 St. JoHN's L. Rev. 185 (1945).

4. Ineligibility is not restricted to professional activities, but also applies to any licensed occupation which is limited to persons with certain moral qualifications. Thus, exfelons may not obtain New York City taxi licenses. 3 Susrey 284. It is questionable whether a pardon will remove this ineligibility. Id. at 285.

And released prisoners who are under probationary restrictions may have additional limitations on their choice of occupations. See Spaulding v. United States, 155 F.2d 919 (6th Cir. 1946) (probation officer would not allow parolee to take job as salesman).

5. Deprecated by judges and jurors, recidivist statutes are rarely applied. See Note, 48 CoL. L. Rev. 238, 251 (1948). They are designed to deter repetitious criminal behavior by threatening progressively increasing sentences on the basis of the number of prior convictions. Since it is doubtful that they succeed in this respect, however, they have been harshly criticized. See Watte, The Prevention of Rapeated Crnos 18 ct seq. (1943).

For discussion of possible remedies for recidivists see note 19 infra.

6. The writ is sometimes called coram vobis. This terminology stems from English usage: nobis (before us, the King) being in the Kings Bench; vobis (before you, the Justices) being in the Common Pleas. Note, $10 \mathrm{NzB}$. L. BuLn 314 (1932). In the United States, the former appellation prevails, although some courts use the latter in reference to a writ brought before an appellate court. Orfield, The WWrit of Error Corain Nobis in Civil Practice, 20 VA. L. REv. 423, 425 (1934). 
time after judgment, ${ }^{7}$ either by those in prison or by those who have served their time. ${ }^{8}$ It can be used to vacate sentence on the basis of facts which, if known at time of trial, would have prevented the judgment." At one time the writ was of limited usefulness, since it generally covered only clerical errors, coverture, infancy, death of a party before judgment, and insanity at time of plea. ${ }^{10}$ But state courts have gradually extended these limited grounds to include guilty pleas obtained through fraud, duress, or mistake; ${ }^{11}$ convictions based on perjured testimony; ${ }^{12}$ and deprivation of right to counsel. ${ }^{13}$

7. Courts have disagreed on the availability of the writ after the contested judgment has been affirmed on appeal. Those denying availability ustally did so on the ground that the appeal deprived the trial court of jurisdiction by removing the record to the appellate court. But this rationale is rapidly falling into disfavor and a strong majority of courts now hold that the writ is available even after appeal. See Note, 145 A.L.R. 818 (1943). While sanctioning issuance after affirmance, some courts require that permission to apply to the trial court must first be obtaincd from the affirming appellate court. Ibid. E.g., Strang v. United States, 53 F.2d 820 (5th Cir. 1931).

At common law, issuance was entirely at the trial court's discretion, but modern cases allow appellate review of denial by the trial court. See Orfiecd, Criminal ProCEDURE FROM ARREST TO APPEAL 524 (1947).

8. E.g., State ex rel. Lopez v. Killigrew, 202 Ind. 397, 174 N.E. 808 (1931) (rcleased) ; Bojinoff v. People, 299 N.Y. 145, 85 N.E.2d 909 (1949) (confined); Matter of Hogan v. Court of General Sessions, 296 N.Y. 1, 68 N.E.2d 849 (1946) (released).

9. The writ at one time was available in both civil and criminal proceedings as an extension of the trial court's power to modify judgments at subsequent terms. It is generally held to have been superseded in civil cases by statutory motion, such as a motion to vacate. See Orfield, The Writ of Error Coram Nobis in Ciril Practice, 20 VA. L. REv. 423, 426 (1934). For discussions of the origin and development of the writ sce Freedman, The Writ of Error Coram Nobis, 3 TEMP. L.Q. 365 (1929) ; Moore \& Roger', Federal Relief from Civil Judgments, 55 YALE L.J. 623, 669 et seq. (1946); Comment, 34 CORNELI L.Q. 596, 598 (1949) ; 37 HARv. L. Rev. 744 (1924).

10. See sources cited in note 9 supra. See also Notes, 10 A.L.R. 526, 648 (1921) (clerical errors); 121 A.L.R. 267 (1939) (convicted when insane).

11. E.g., Dobosky v. State, 183 Ind. 488, 109 N.E. 742 (1915) ; Sanders v. State, 85 Ind. 318 (1882) ; State v. Calhoun, 50 Kan. 523, 32 Pac. 38 (1893). See Note, 30 A.L.R. 686 (1924).

12. E.g., Skipper v. Schumacher, 124 Fla. 384, 169 So. 58 (1936); People v. Dabbs, 372 Ill. 160, 23 N.E.2d 343 (1939).

13. E.g., Bojinoff v. People, 299 N.Y. 145, 85 N.E.2d 909 (1949); sec Fluty v. State, 224 Ind. 652, 71 N.E.2d 565 (1947), 45 MICH. L. REv. 1049. Discussion of other possible grounds is found in Orfield, Crininal. Procedure from Arrest to Appens 522 at seq. (1947).

The prevailing view is that the writ is not available for newly discovered evidence. 24 CoL. L. REv. 797 (1924) ; Note, 33 A.J.R. 84 (1924). But an increasing minority of courts either allow such use or indicate that they would in exceptional circumstances. See George v. State, 211 Ind. 429, 439, 6 N.E.2d 336, 340 (1937) (if evidence is of such conclusive nature that the judgment was "not right upon the merits"); Anderson v. Buchanan, 292 Ky. 810, 168 S.W.2d 48 (1943), 32 Kx. L.J. 296 (1944). But cf. Jones v. Commonwealth; 269 Ky. 779, 108 S.W.2d 816 (1937), 31 Kx. L.J. 86 (1942).

For discussion of the need in the federal courts for a motion for a new trial based on newly discovered evidence, without time limit, see note 30 infra. 
Insofar as prisoners are concerned, opportunities for relief in the federal courts are comparably broad. Under Section 2255 of the new Judicial Code, prisoners may move the sentencing trial court for relief on the grounds inter alia that the court lacked jurisdiction or that the trial procedure violated the Constitution. ${ }^{14}$ This Section generally replaces habeas corpus by providing that habeas may be used only if the new motion is "inadequate or ineffective to test the legality" of imprisonment. ${ }^{25}$ If available, habeas is brought in the court of the district of confinement. Theoretically, it is effective only against judgments rendered without "jurisdiction." But the courts have so expanded the common law concept of "jurisdictional" defects that actually a prisoner can use the habeas writ against any judgment which violates due process or fairness in criminal proceedings. ${ }^{10}$ In fact, recent decisions by-pass the outmoded concept of jurisdiction and treat directly the constitutional issues involved. ${ }^{17}$ Thus, the modern habeas writ and the motion under Section 2255 are substantive equivalents.

Except for the "remedy" of executive pardon, ${ }^{18}$ however, federal proced-

14. Available only to prisoners under sentence of a court crented by Congress, the full grounds for $\$ 2255$ are "that the sentence was imposed in violation of the Constitution or laws of the United States, or that the court was without jurisdiction to impose such sentence, or that the sentence was in excess of the maximum authorized by law, or is otherwise subject to collateral attack. ..." 28 U.S.C. \$2255 (Supp. 1949), as amended, 28 U.S.C.A. $\$ 2255$ (Supp. 1949). For a discussion of the section's legislative history see United States v. Calp, 83 F. Supp. 152 (D. MId. 1949).

15. "An application for a writ of habeas corpus in behalf of a prisoner who is authorized to apply for relief by motion pursuant to this section, shall not be entertained if it appears that the applicant has failed to apply for relief, by motion, to the court which sentenced him, or that such court has denied him relief, unless it also appears that the remedy by motion is inadequate or ineffective to test the legality of his detention." 28 U.S.C. $\$ 2255$ (Supp. 1949), as amended, 28 U.S.C.A. \$2255 (Supp. 1949). This limitation on the use of habeas seems to be the purpose for which $\$ 2255$ mas passed. See Parker, Limiting the Abuse of Habeas Corpus, 8 F.R.D. 171, 175 (1949).

Since $\$ 2255$ only covers prisoners sentenced by a court created by act of Congress, habeas still can be used to attack a court-martial conviction. But the existence of additional cases in which federal prisoners may still use the habeas writ is problematical, since the scope of $\$ 2255$ is as broad as the present scope of habeas. One court has held that if the sentencing court is far away from the district of confinement, the excessive time involved in obtaining a hearing under $\$ 2255$ makes the remedy inadequate, and therefore justifies use of habeas. See Stidham v. Swope, 82 F. Supp. 931 (D. Cal. 1949) (sentencing court, Missouri; confinement, Alcatraz).

16. For an excellent discussion of the expansion of habeas in terms of contemporary attitudes toward criminal administration see Note, 61 HARv. L. REv. 657 (1948). See also Note, 24 CorNell L.Q. 270 (1939).

17. See Sunal v. Large, 332 U.S. 174, 182, 187 (1947); Waley v. Johnston, 316 U.S. 101, 104-5 (1942); Bowen v. Johnston, 306 U.S. 19, 24 (1939).

18. While pardons may be granted any time after commission of a crime, practically all are granted after conviction and most of those only after service of sentence. In 1935, for example, 152 of 154 federal pardons were granted after completion of sentence. 1 SURVEY 25 n.9.

When claims of unjust conviction do not fit within existing judicial remedies, peti- 
ure provides no method by which persons who have served their time can upset unjust convictions. ${ }^{19}$ This discrimination against the ex-prisoner is neither reasonable nor fair. Through lack of funds or ignorance of their rights, many prisoners are unable to attack their convictions effectively until after release. There is no reason why the end of incarceration should cut off their chance to end the other disabilities of a felony conviction. ${ }^{20}$

The most obvious method of giving ex-prisoners the same protection as prisoners is to amend Section 2255 of the Code to include former convicts. But in lieu of statutory amendment, the federal courts might themselves provide relief by installing coram nobis or its equivalent. While the writ

tioners are referred to the pardoning power as their only solution. Sec, e.g., Reid v. United States, 149 F.2d 334 (5th Cir. 1945) ; Kelley v. United States, 138 F.2d 489, 492 (9th Cir. 1943) (concurring opinion). But since a pardon does not necessarily cstablish innocence, the former convict's name is not fully "cleared." His civil rights such as voting and holding office are restored, and he becomes competent to serve as a juror or witness; but he cannot regain forfeited offices, the conviction may still be counted under an habitual criminal statute, and he may not be reinstated to a lost profession. See 3 Sunvey 293.

19. See Note, 24 CoRNecl L.Q. 270 (1939). Moreover, habeas will not even lie during a probationary parole period. Van Meter v. Sanford, 99 F.2d 511 (5th Cir. 1938). It is also doubtful if relief is available to incarcerated recidivists who want to attack prior convictions. They sometimes have been told that such objection should have been raised when they were sentenced as second offenders, and that failure to do so bars further review. See Gayes v. New York, 332 U.S. 145, 149 (1947), criticized in [1948] WIs. L. Rev. 235; United States v. Moore, 166 F.2d 102 (7th Cir. 1948). But cf. United States v. Steese, 144 F.2d 439 (3d Cir. 1944).

It has been suggested that state prisoners serving an increased sentence based on a prior federal conviction may attack the prior conviction by applying for habeas corpus in the state courts. See United States v. Rockower, 171 F.2d 423, 426 (2d Cir. 1948). However, habeas is only available against judgments which illegally restrain the liberty of the petitioner. Having served the prior sentence he is no longer "restrained" by it. Habeas might be allowed, if at all, only after the petitioner had served the length of time he would have had to were it not for the prior conviction. Also, habcas might be allowed in attacking the sentence under the second conviction on the ground that since the sentence 'was based on a prior judgment which was void, the court lacked jurisdiction.

Even assuming the availability of habeas, the writ appears to be of questionable value in situations involving prior federal convictions. The dictum in the Rockower case, supra, is based on People ex rel. Harrison v. Jackson, 298 N.Y. 219, 82 N.E.2d 14 (1948), which involved two convictions rendered by courts of the same state. The Rockozer dictum may be acceptable where only state court judgments are challenged. But state court habeas petitions which question the validity of a prior federal conviction would create difficult jurisdictional problems. See treatment in Des Moines Navigation \& R. Co. v. Iowa Homestead Co., 123 U.S. 552 (1887) (collateral attack on federal civil judgment in a state court). Allowing attack by coram nobis in the federal court which rendered the prior sentence would eliminate these difficulties.

20. See Roberts v. United States, 158 F.2d 150 (4th Cir. 1946); State cx rcl. Lopcz v. Killigrew, 202 Ind. 397, 174 N.E. 808 (1931). But see Tinkoff v. United States, 129 F.2d 21, 23 (7th Cir. 1942). 
has definitely been abolished from federal civil procedure, ${ }^{21}$ its availability in criminal procedure has been left open by both the Federal Rules of Criminal Procedure and the new Judicial Code. A preliminary draft of the Rules specifically states that they make no provision regarding coram nobis, and that the power of courts to grant relief not provided for in the rules is left intact. ${ }^{22}$ And while a revisor's note to Section 2255 asserts that the section "restates, clarifies, and simplifies the procedure in the nature of the ancient writ of error coram nobis," 23 actually the section adopts only part of its procedural characteristics. ${ }^{24}$

Although the Supreme Court has declined to rule on the availability of coram nobis in federal courts, ${ }^{25}$ use of the writ in lower federal courts has recently increased. Some courts have heard and granted hearings on motions in the nature of coram nobis; ${ }^{26}$ others have escaped ruling on the

21. FED. R. CIv. P. 60(b).

22. "No express provision is made with respect either to providing for relief or to barring relief under the common law writ of error coram nobis ... [nor is the] existing power of the court to grant any type of relief from judgments or orders which is not expressly provided for in the rules [limited]." Fed. R. Crna. P., Szco:ro PrearrurNARY DrafT, Note to rule 35, p. 131 (Feb. 1944).

23. 28 U.S.C. $\$ 2255$ (Supp. 1949).

24. The only procedural similarity is that motions under $\$ 2255$ and coram nobis are both brought in the sentencing trial court. There similarity ends: Section 2255 is only available to confined persons, see note 14 supra, while coram nobis is available to persons in or out of confinement, see note $S$ supro.

The meaning of the Revisor's note is not clear. In view of the broad statement in the draft of the Rules, it does not seem that coram nobis was abolished. In United States v. Rockower, 171 F.2d 423, 425 (2d Cir. 1948), the second circuit specifically declared that the question was not answered by the Code or by the Federal Rules.

25. United States v. Mayer, 235 U.S. 55, 69 (1914) : "[E]ven if it be assumed that in the case of errors in certain matters of fact, the district courts may exercise in criminal cases-as an incident to their powers expressly granted-a correctional jurisdiction at subsequent terms analogous to that exercised at common law on writs of error coram nobis ... as to which we express no opinion, that authority would not reach the present case [prejudicial misconduct of a United States Attorney and concealed bias of juror on voir dire examination]." The Court then said that this power existed, if at all, only "in those cases where the errors were of the most fundamental character, that is, such as rendered the proceeding itself irregular and invalid." But of. Waley r. Johnston, 316 U.S. 101, 105 (1942) (approves existence by implication).

26. Allen v. United States, 162 F.2d 193 (6th Cir. 1947) (insanity at time of plea); Roberts v. United States, 158 F.2d 150 (4th Cir. 1946) (mental incompetence to plead, denial of counsel); Garrison v. United States, 154 F.2d 105 (5th Cir. 1946) (material witnesses perjured testimony); United States v. Steese, 144 F.2d 439 (3d Cir. 1944) (denial of counsel) ; United States v. Mahoney, 43 F. Supp. 943 (W.D. La. 1942) (denial of counsel). The writ has been granted even in the face of strong government denial of its existence. See United States v. MIonjar, 64 F. Supp. 746 (D. Del. 1945).

While admitting the existence of the writ, some courts have denied issuance on the basis that the grounds asserted did not come within the dictum in the Mayer case, quoted note 25 supra, or that petitioners failed to substantiate their allegations. See Barber $v$. United States, 142 F.2d 805 (4th Cir. 1944) (denied time to obtain evidence); Meri- 
writ's availability by assuming its existence arguendo and then denying issuance on the grounds asserted, ${ }^{27}$ or because of laches. ${ }^{28}$

If coram nobis is to be the method for giving relief to wrongly convicted ex-prisoners, the federal courts should include within its scope the present grounds under which federal habeas corpus proceedings and a motion under Section 2255 may be brought. Moreover, the courts should grant a hearing on the merits unless, as provided in Section 2255, the motions, files and records in the case conclusively show that relief is not in order. ${ }^{29}$ Finally, to insure an adequate remedy, coram nobis should be available without time limit, since application of laches would unjustly penalize the impecunious and the ignorant who lack the aid of competent counsel..$^{30}$

Those who oppose broad relief, without time limit, assert that federal courts will be swamped with a small avalanche of motions, some brought years after judgment when evidence has dissipated and witnesses have departed. But the spectre of judicial overwork of ten fails to materialize, and even if it does, it has no bearing on the need for expunging unjust convictions. ${ }^{31}$

dith v. United States, 138 F.2d 772 (6th Cir. 1943) (perjured testimony); Kelley v. United States, 138 F.2d 489 (9th Cir. 1943) (insufficiency of indictment); United States v. Gardzielewski, 135 F.2d 271 (7th Cir. 1943) (material witness later judged insane). For denials on the basis of failure to substantiate allegations see, e.g., Pierce v. United States, 157 F.2d 848 (5th Cir. 1946) ; Spaulding v. United States, 155 F.2d 919 (6th Cir. 1946).

27. Kramer v. United States, 166 F.2d 515, 518 (9th Cir. 1948) (issue already raised by motion to vacate).

28. United States v. Moore, 166 F.2d 102 (7th Cir. 1948) (18 years after conviction); United States v. Rockower, 171 F.2d 423 (2d Cir. 1948) (same period); United States v. Buhler, 48 F. Supp. 159 (M.D. Pa. 1942) (6 years after conviction). Contra: United States v. Steese, 144 F.2d 439 (3d Cir. 1944) (9 years after conviction).

29. 28 U.S.C. §2255 (Supp. 1949), as amended, 28 U.S.C.A. §2255 (Supp. 1949). See the forthright comment by Judge Evans, note 31 infra.

By incorporating the recently adopted statutory provision for court reporters in all district courts to record criminal proceedings, the new Judicial Code has insured the continued existence of accurate records in future cases. 28 U.S.C. $\$ 753$ (a) (b) (Supp. 1949).

30. There is another gap in federal criminal procedure, unreachable by coram nobis, which also should be filled. No provision exists for the granting of a new trial, without time limit, on the basis of newly discovered evidence of fundamental importance. The need for such a motion was commented upon before the adoption of the Federal Rules of Criminal Procedure. See National Commission on Law OdSERvance AND Enforcement, Report on Criminal Procedure 44 (1931); 3 Survey $296-7$.

As drafted by the Advisory Committee, Rule 33 would have allowed a motion for a new trial on this basis without time limit. But as promulgated by the Supreme Court, Rule 33 applies a two year limitation. For an excellent discussion criticizing the two year limitation see Dession, New Rules of Criminal Procedure II, 56 Y YLE L.J. 197, 232-4 (1947).

31. "That there has been a vast increase in ... [habeas] petitions ... which have imposed great burdens upon the courts, I cannot deny. Even though there were thrice this increase in number, the argument that we are too busy to hear applications... 